\title{
Steroid Use Status
}

National Cancer Institute

\section{Source}

National Cancer Institute. Steroid Use Status. NCI Thesaurus. Code C135483.

An assessment of steroid usage as a condition of disease response to therapy. 